\title{
An Examination of the Relationship Between Desistance and Attitude Towards Life Sentence Punishment Among a Sample of Incarcerated Aged-Delinquent Offenders Housed at the Louisiana State Penitentiary
}

\author{
Geraldine Doucet \\ Department of Criminology \& Criminal Justice \\ Nelson Mandela College of Government and Social Sciences \\ Southern University and A \& M College, Baton Rouge, Louisiana
}

\begin{abstract}
This study examines the relationship between desistance and attitude towards life sentence punishment among a sample of incarcerated aged-delinquent offenders housed at the Louisiana State Penitentiary. The study utilized a cross-sectional-survey research design and a primary data source. The primary data source comes from the Louisiana State Penitentiary based on self-reported face-to-fact survey interviews initially taken May 2007 and followed by face-to-fact interviews officially obtained data over the period of a year and eight months regarding the same sample population. Results suggested that in the Before study, using self-reported data, that human capital variables were not statistically reliable in distinguishing desistance among the sample of aged delinquents. There were only two social capital variables that were statistically reliable in distinguishing desistance among inmates. These variables were relationship with mother, which had the most predictive power regarding desistance process, followed by the who raised the inmate variable. The strongest of all variables in this study was the punishment adjustment, in particularly the psychological coping one. Further, the data suggested that inmates' attitudes toward a life-sentence punishment were not as statistically reliable in distinguishing desistance. The After-study results showed no predictability with respect to desistance among any of the predictor variables. When comparing the desisters among the aged delinquents, juvenile lifers (younger group) desisted less than young adult lifers (older group), although no significant differences were found in the desistance rate of these aged-delinquents' subgroups in the sample population.
\end{abstract}

Keywords: Offenders, Age, Demographics, Desistance, Delinquents, Crime, Juvenile, Punishment, Incarceration, Offenders, and Justice system.

DOI: $10.7176 /$ PPAR/11-7-03

Publication date:August $31^{\text {st }} 2021$

\section{INTRODUCTION}

According to official sources, violent juveniles commit a remarkably high number of crimes (OJJDP, 1996; Tolan \& Gorman-Smith, 1998; Cook \& Laub, 1998; Zimring, 1998; Siegel, Welsh, \& Senna, 2003). The high rates of homicides, rapes, robberies and aggravated assaults committed by juveniles between 1983 and 1993 became the driving force behind the nation's alarming increase in juvenile crime over the last decades. This level of violence has contributed to the increased practice of transferring juveniles to adult criminal courts and sentencing them to life in adult prisons (Feld, 1987; Bennett, DiIulio, \& Walters, 1996; Torbet, Gable, Hurst, Montgomery, Szymanski \& Thomas, 1996; Redding, 2003). Empirical research shows that these serious, violent, chronic offenders constitute only 6 to 8 percent of the total juvenile offender population; however, they are responsible for a disproportionately large number of offenses (Snyder \& Sickmund, 1995; Mukherjee, 1997; Siegel, Welsh \& Senna, 2003).

According to the U. S. Surgeon General (2001), violent juveniles are involved in a wide range of offense types and do not usually begin their criminal careers with a serious violent offense. While this developmental pathway varies, depending on the types of behavior being monitored, studies generally show that violent careers begin with relatively minor forms of anti-social or delinquent behavior (Shalala, 2001; Loeber, 1996; Elliott, 1994). These acts later increase in frequency, seriousness, variety, and frequently progress to serious violent acts (Elliott, 1994; Loeber, Farrington, \& Waschbusch, 1998; Moffitt, 1993; Tolan \& Gorman-Smith, 1998).

Empirical studies further reveal that juveniles who commit crimes typically commit them in the company of their peers (Gonzales, Schofield \& Schmitt, 2005; Mukherjee, 1997). A study conducted in 2005, Gonzales, Schofield \& Schmitt found that offenders, age13 and under, are more likely to commit crimes in pairs and groups than are the 16 and 17 year old offenders. They found that approximately 40 percent of juvenile offenders commit most of their crimes with others.

The consensus in Criminology, based on empirical studies, official crime data, and self-reported studies, is that most violent juveniles begin their violent behavior during adolescence (O'Shaughnessy, 2004; Shalala, 2001; Loeber, Farrington, \& Waschbusch, 1998; Tolan \& Gorman-Smith, 1998; Kelley, Huizinga, Thornberry, \& 
Loeber, 1997; Moffitt, 1993; Tolan, 1987) with few exceptions and continue their violent behavior beyond adolescence (Loeber et al., 1998; Tolan \& Gorman-Smith, 1998; Kelley et al., 1997; Kelley, Loeber, Keenan, \& DeLamatre, 1997; Moffitt, 1993; Tolan, 1987). Although most violent juveniles begin their violent careers during adolescence, the exception is for those who commit the most serious violent acts and who continue their violent behavior beyond adolescence; they begin during childhood (Loeber et al., 1998; Moffitt, 1993; Tolan, 1987; Tolan \& Gorman-Smith, 1998). Despite the enormous theories and empirical evidence to explain crime data across the globe, none of these studies has been devoted to study the relationship between desistance and attitude towards life sentence punishment, particularly among aged-delinquent offenders housed in Angola prisons. Therefore, this current study is structured to examine the relationship between desistance and attitude towards life sentence punishment among a sample of incarcerated aged-delinquent offenders housed at the Louisiana State Penitentiary (Angola) to inform criminal justice policy reforms.

\section{LITERATURE REVIEW}

\section{Desistance and Incarceration}

The notion that the experience of prison in itself acts as a deterrent is rooted in the specific deterrence theory (Andenaes, 1968) which predicts that individuals experiencing a more severe sanction are more likely to reduce their future criminal activities. The degree to which punishment reduces criminal recidivism (which leads to desistance) has been extensively studied, though few efforts have examined the extent to which sanctions are effective (Yv, 2004). Empirical studies (e.g. Blumstein, Farrington, \& Moitra, 1984; Blumstein, Cohen, \& Farrington, 1988; Warr, 1998; Laub, Nagin, \& Sampson, 1998; Nagin \& land, 1993; Sampson \& Laub, 1993; Bushway, Piquero, Broidy, Cauffman, \& Mazerollo,2001; Farrington, 2003; Piquero, Farrington, \& Blumstein; 2003; Nagin, 2005; Bushway, 2007) have reported on the factors that influence desistance from crime and on the behavioral (or life) changes; however, most of the studies have focused on adults and fewer on serious juvenile offenders (Losel \& Bliesener, 1990; Laub \& Sampson, 2001).

The literature on the effectiveness of sanctions does not indicate which approaches are the most effective in reducing continued criminal offending or anti-social behavior among adults, nor juveniles treated as adults (Mulvey, et al., 2004; Cunningham \& Henggeler, 1999). Long terms of incarceration can remove an individual from involvement in the job market and increase the likelihood of a downward spiral of events making crimes a more reasonable activity (Fagan \& Freeman, 1999; Sampson \& Laub, 1995). This fact is true for lifers in Louisiana; this condition will always exist. Although inmate lifers have been removed from the free world job market system, they are nonetheless given access to gainful employment at LSP where they can obtain meaningful job skills and earn some compensation, although the amount is low. Those who do work are assigned to menial tasks that they perform for only a few hours a day. Although the jobs available in prison are usually not of their choice, they may still provide some opportunities, no matter how limited. Inmate skilled labor is utilized in the production of institutional furniture, clothing, janitorial products, dentures and other goods and services, some of which were once outsourced (M. Thomas, personal communication, May 22, 2007).

Inmates can learn the importance of employee accountability, pride in job performance, a good work ethic, the ability to work with others, and the ability to work productively under supervision. A few prisons are training inmates to use digital printing technology, and telemarketing in an attempt to give them a better chance to develop technological skills and provide cheap labor to the community. Most offenders accomplish the community service behind prison walls. Those who have reached a supervision level where they can work in the community under the observation of prison staff return to the confines of prison at the end of the day. On the other hand, inmates who refuse to work are labeled "uncooperative" and risk losing time off for "good behavior," as well as privileges, such as library access, participation in inmate organizations, and recreation activities.

\section{Attitudes toward Punishment}

The use of prisons to control crime has increased in frequency in the last decade. Several surveys have indicated that both the public and offenders consider prison to be the most severe or effective form of punishment for criminal behavior (Doob, Sprott, Marinos, \& Varma, 1995; Spelman, 1995; Van Voorhis, 2004; Van Voorhis, Browning, Simon, \& Gordon,1997). Most recently, mandatory minimum sentencing policies have gained widespread popularity throughout the United States (Gendreau, Goggin \& Cullen 1999). Three schools of thought dominate the punishment phase of criminal justice. The first view is that prisons definitely suppress criminal behavior. Given the unpleasantness of prison life and the negative social stigma associated with incarceration, placing criminals in prison should serve as a deterrent to later criminal behavior. The second, a viewpoint characterized by experts as the "schools of crime," proposes just the opposite, that is, that prisons increase criminality (Gendreau, Goggin, \& Cullen, 1999). This view holds that the barren, inhumane, and psychologically destructive nature of prison makes offenders more likely to recidivate upon release. The third perspective, referred to as the "minimalist/interaction" view, contends that the effect of prison on offenders is, 
for the most part, minimal (Gendreau, Goggin, \& Cullen, 1999). According to this view, prisons are essentially "psychological deep freezes" in that offenders enter prison with a set of anti-social attitudes and behaviors that hardly alter due to incarceration (Gendreau, Goggin, \& Cullen, 1999). This perspective also suggests that lower risk offenders may be more adversely affected by greater lengths of incarceration through exposure to an environment typically dominated by high risk, hard-core inmates (Gendreau, Goggin, \& Cullen, 1999).

Research on one's attitude toward punishment essentially depends on an individual's philosophy of life and certain variables that influence it, such as the standard of education and age (Kuhn,n.d.). An International Victimization survey study conducted among several countries corroborates the results that males are slightly more punitive than females. A person's educational level and age also play a key part in matters of attitudes towards punishment, except for the United States of America, where there is a minimal and insignificant effect (Brillon, 1983). In a study by Wilcox and Steele (2003) on the attitude of inmates toward the death penalty, they found that executions do not deter violent crime. Their study further stated that inmates indicated that most capital crimes are unplanned and that the criminal justice system is "fundamentally flawed," opinions generally shared by experts in the field (Radelet \& Ackers, 1996).

\section{METHODOLOGY}

This study utilized a cross-sectional-survey research design. A sample size of 144 respondents were used in this study. A disproportionate-stratified probability sampling method utilizing a random number table will be applied. This study consists of two phases (the Before and the After study). The key variable used to predict desistance in this particular study is human capital and adjustment of punishment for the purpose of analysis. The key variable was measured in a Before self-reported study on May 2007 and an After official-report study on December 2008. The Before data were obtained from a self-reported survey given to inmates at LSP in May 2007. The After data were obtained from official reports provided by LSP's Classification Department. Violent aged-delinquent male offenders serving life sentences without the benefit of parole prior to age of 18 and up to age 21 were the main variables of interest in this study. Aged juvenile delinquents fall into two age categories, juveniles who were 18 to 21 years old at the time of their crimes and juveniles who were 17 years old or younger.

For the purpose of this study, the age group of 18-21 are referred to as young adult lifers (McShane \& Williams, 1989; Capaldi, \& Patterson, 1996). The survey instrument used, LSP Aged-Delinquent Questionnaire, was modeled from a previous survey, Old Prisoner Questionnaire, designed by Dr. James Marquart, Corrections expert researcher, and myself. This survey as well as the previous survey was designed for the incarcerated inmate population to obtain a variety of questions related to their past and present lifestyle (family, beliefs/attitude, health behavior, prison adjustment, education, criminal history, etc...) prior to their incarceration and since their incarceration. Based on the desistance literature review, modifications of the instrument were made.

As part of the survey design, a self-designed, detailed questionnaire (LSP Aged Delinquent Questionnaire) was used to conduct the face-to-face interviews. In administering the survey instrument, inmates were gathered into classroom settings or meeting areas and were asked to complete the survey (using the special designed LSP Aged Delinquent Questionnaire). The survey required approximately 25 to 30 minutes for completion. The purpose and instructions for taking the survey were personally given by the author of this study with all inmates volunteering to participate in this project.

Statistical techniques utilized in this study were descriptive statistics, nonparametric chi-square, and logistic regression. Descriptive statistics were used to identify and describe the sample population and their self-reported responses. Chi-square statistics were performed to measure the significant difference between desisters and nondesisters among juvenile lifers and young adult lifers (in the sample aged delinquent population). Logistic regression is a statistical procedure used to examine the relationship and predictability of a criterion variable that is categorical from two or more predictor variables. The value that is being predicted in logistic regression is actually a probability, which ranges from 0 to 1 . More precisely, logistic regression specifies the probabilities of the particular outcomes for each participant or case involved.

In this study binary logistic regression was used to predict desistance or non-desistance among aged delinquents based on selective factors. Since desistance is a dichotomous criterion variable, logistic regression is appropriate in identifying the differences within the age-delinquent offenders who desist and those who do not desist.

A model with more than one predictor variable can be represented as:

$$
\operatorname{Prob}(\mathrm{Y})=\frac{\mathrm{e}^{\mathrm{z}}}{1+\mathrm{e}^{\mathrm{z}}}
$$

Where $\mathrm{Z}$ is the linear combination,

$$
\mathrm{Z}=\mathrm{Z}=\beta_{0}+\beta_{1} X_{1}+\beta_{2} X_{2}+\cdots+\beta_{p} X_{p}
$$


$\mathrm{B}_{0}$ and $\mathrm{B}_{1}$ are coefficients estimated from the data and e is the base of the natural logarithms. When plotted, the logistic regression curve should be shallow with a slope close to zero for very high and very low values of $\mathrm{X}$. If $\mathrm{X}$ and $\mathrm{Y}$ are related, then between the very high and very low values of $\mathrm{X}$ the slope of the curve will be steeper. This means it is significantly different from zero (Menard, 1995). This research study was a cross-sectional study that allowed for a Before face-to-face contact with the subjects where they self-reported the data and an After (or follow-up) contact with LSP officials within a year and eight months to examine inmates' files for any official write-ups within that time period.

\section{DATA ANALYSIS AND FINDINGS}

In all a total 144 sample population was used in this study. The descriptive analysis of the demographic characteristics of the offenders is discussed by using bar-graphs and pie-charts. Figure 1 discussed the ageddelinquent status of the offenders. Figure 1 shows that the aged-delinquents in the sample population, consisted of 77 percent juvenile lifers (under age 17) and 23 percent young adult lifers (age 18 to 21).

\section{Demographic Analysis of the Aged-Delinquent of LSP Sample-Population}

Figure 1: Age-Delinquent Status

\section{AGE- DELINQUENT STATUS}

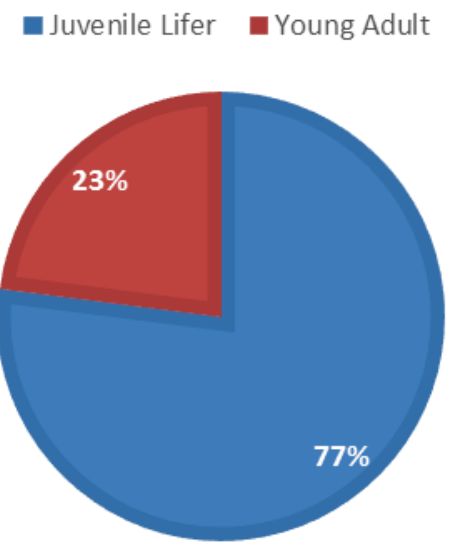

\section{Source of Data: Field Data, LSP}

Figure 2 shows offenders' status in the sample population. The data revealed that about twenty-nine percent $(29 \%)$ of the respondents reported being first-time offenders, and seventy-one $(71 \%)$ percent were habitual offenders (see Figure 2 for more details).

Figure 2: Offenders Status

\section{Offenders Status}

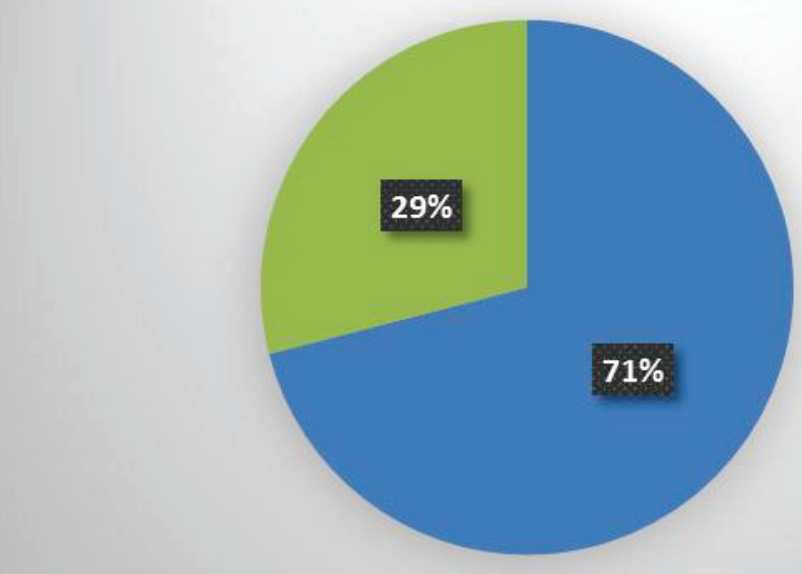

- Habitual Offender

First-Offender

Source of Data: Field Data, LSP

Figure 3 shows that offenders' race type in the sample population. The data revealed that Eighty-four 
percent $(84 \%)$ of the participants were non-White (Black, Hispanic, and Native American) and $16 \%$ percent were White. Among the non-White, Blacks made up 81 percent of the population (see Figure 3 for more details). Figure 3: Offenders Race Type



\section{Source of Data: Field Data, LSP}

Figure 4 discusses the data for crime committed by offenders. All of the participants in this sample were violent offenders, of whom approximately 74 percent were convicted on murder charges, 13 percent for rape, 10 percent armed robbery, and 3 percent for aggravated robbery (see Figure 4 for more details). The mean age at the time of the study was 36.4 with a standard deviation of 10.55 . The mean conviction age was 17.97 with a standard deviation of 6.93 .

Figure 4: Crime Committed by Offenders

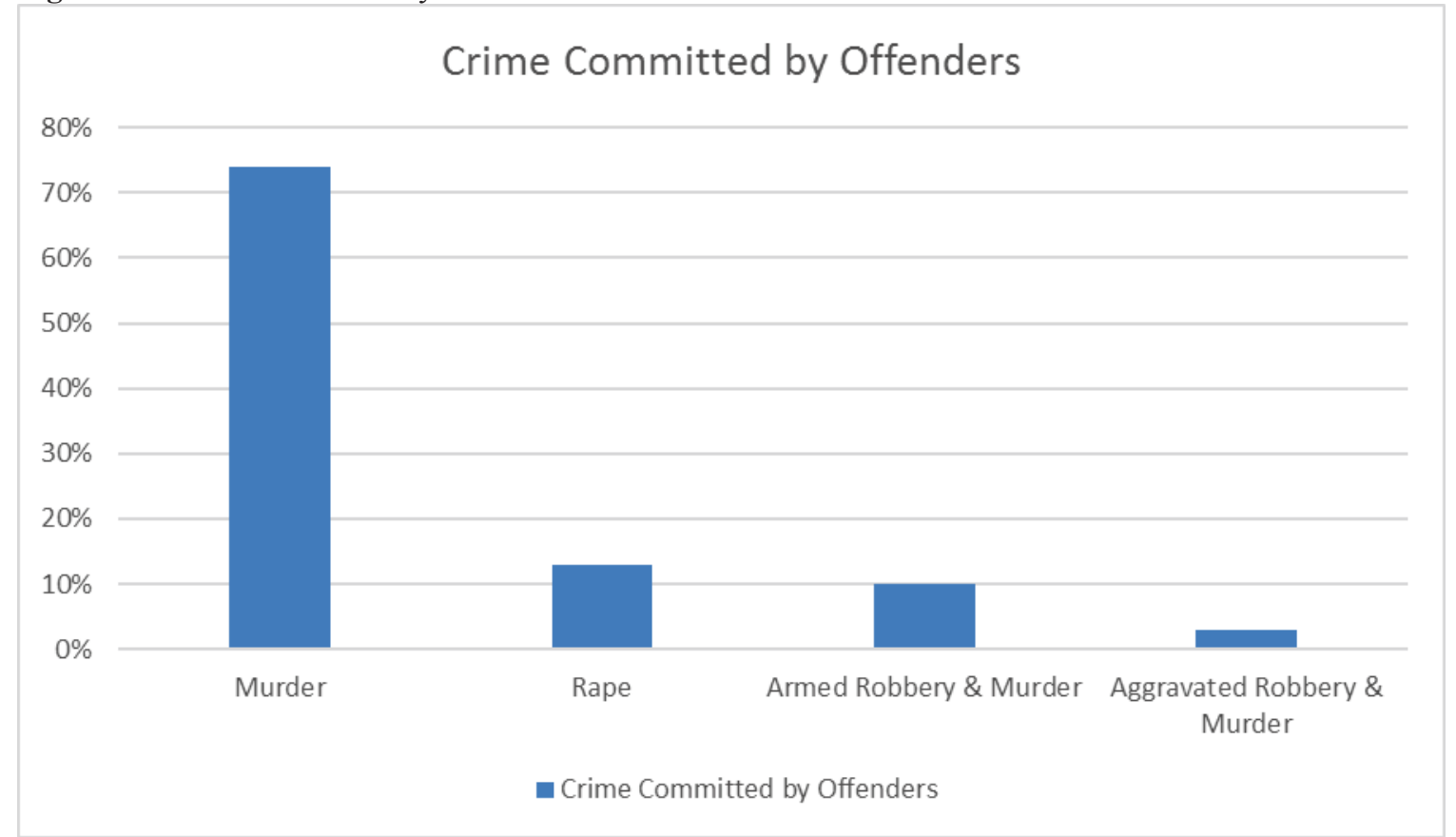

Source of Data: Field Data, LSP

In discussions with several LSP classifications officers, the longer an inmate serves time at LSP, the least likely he will be involved in any prison infractions. Those inmates have become acclimated to their prison environment and valued their freedom and privileges outside the cells, while learning to avoid situations that can get them into trouble. LSP classification officer Merritt Thomas suggested that often this wisdom comes as the 
inmate matures.

\section{How Desistance is Predicted from Attitude towards a Life sentence Punishment}

A Binary Logistic Regression technique was computed to determine which punishment variables were predictors of the desistance process. Two punishment variables measured the respondents' adjustment to prison (e g., how they cope with their prison situations, and their involvement in recreational and social activities). Another two punishment items addressed their beliefs about whether the threat of adult punishment deters one from crime and whether they believe juveniles should be sentenced to adult prisons.

Regression results showed that the overall model of the four attitudes-toward-life-sentence-punishment predictors (activities involved in, attitudes toward life sentence, and adjustment to prison) were not statistically reliable in distinguishing between young adult lifers and juvenile lifer offenders with

-2 Log Likelihood $=184.850$, Chi Square $=4.628, d f=4, \mathrm{p}>.05$ (See Table 1$)$.

Table 1

Overall Model Fit Result

\begin{tabular}{lrcrc}
\hline \multicolumn{2}{l}{-2 Log } & & \\
\multicolumn{1}{l}{ Model Likelihood } & & Chi Square & $d f$ & $P$ \\
\hline Intercept & -.541 & & & .328 \\
Final & 184.850 & 4.628 & 4 & \\
\hline
\end{tabular}

$\mathrm{x}^{2}=4.628, d f=4, p=.328$, Cox and Snell R Square $=.032$

The Wald Criterion (See Table 2) indicated that all four punishment variables had no predictive power regarding the desistance process. The two attitudes toward life sentence punishment variables' odd ratios showed little change in the likelihood of the desistance process.

Table 2

Regression Coefficients Regarding the Relationship between Attitudes

Toward Life Sentence Punishment

\begin{tabular}{|l|c|c|c|c|c|c|}
\hline \multicolumn{1}{|c|}{ Variable } & B & SE & Wald & Df & P & Exp(B) \\
\hline Adjustment (physical activities) & -.266 & .463 & .331 & 1 & .565 & .766 \\
\hline Attitude of punishment as deterrence & -.207 & .366 & .318 & 1 & .573 & .813 \\
\hline Attitude of punishment of life for juvenile & .546 & .587 & .868 & 1 & .352 & 1.727 \\
\hline $\begin{array}{l}\text { Adjustment } \\
\text { (psychological coping) }\end{array}$ & -.128 & .334 & .147 & 1 & .702 & .880 \\
\hline
\end{tabular}

$\mathrm{x}^{2}=2.893, d f=9, p=.968$, Cox and Snell R Square $=.020$; Overall corrections 66.0

Table 3 shows the Chi Square results pertaining to the difference in the desistance rate between the sampled aged delinquents. A significant difference was not found between the desistance rate of young adult lifers and the juvenile lifer offenders $\left(\mathrm{X}^{2}=2.644, d f=2, p>.05\right)$ at the .05 level.

Table 3

Chi Square Results Regarding the Desistance Rate of Younger and Older Aged Delinquents in the After 2008 Study

\begin{tabular}{llccc}
\hline \multirow{2}{*}{ Age Juvenile Status } & & \multicolumn{2}{c}{ Desistance Rate } & Total \\
\cline { 3 - 4 } Juvenile Lifer & Number & Yes & No & 31 \\
& & 22 & 9 & $21.5 \%$ \\
Young Adult Lifer & Percent & $15.3 \%$ & $6.3 \%$ & 112 \\
& Number & 69 & 43 & $77.8 \%$ \\
TOTAL & Percent & $47.9 \%$ & $29.9 \%$ & 144 \\
& Number & 91 & 53 & $100 \%$ \\
\hline $\mathrm{X}^{2}=2.644, d f=2, p>05$ & & & & \\
\end{tabular}

$\mathrm{X}^{2}=2.644, d f=2, p>.05$

*Note: Within group percentages were computed.

\section{CONCLUSION AND POLICY IMPLICATION}

Overall, the Before study self-reported data suggested that the punishment variables were statistically reliable in distinguishing inmates between desistance and non-desistance, especially their psychological adjustment. The punishment psychological adjustment was most interesting since these aged-delinquent offenders were serving natural life sentences. Moreover, the findings in the Before study, using self-reported data, revealed that in general, human capital variables were not statistically reliable in distinguishing desistance among the sample of 
aged delinquents. There were only two social capital variables that were statistically reliable in distinguishing desistance among inmates. These variables were relationship with mother, which had the most predictive power regarding desistance process, followed by the who raised the inmate variable. The strongest of all variables in this study was the punishment adjustment, in particularly the psychological coping one. Further, the data suggested that inmates' attitudes toward a life-sentence punishment were not as statistically reliable in distinguishing desistance.

On the other hand, the After-study results showed that the only predictability with respect to desistance among any of the predictor variables was employment, particularly, type of work. When comparing the desisters among the aged delinquents, juvenile lifers (younger group) desisted less than young adult lifers (older group), although no significant differences were found in the desistance rate of these aged-delinquents' subgroups in the sample population.

Prison research by Haney (2001) suggests that "the longer someone is incarcerated the more significant the nature of the institutional transformation." Moreover, lifers may start the transformation process sooner than other inmates, since they already know that they are never coming out, and this is their permanent home. Haney also stated that inmates eventually become accustomed to the restrictions institutional life imposes. To cope with these restrictions, they develop various psychological mechanisms to adjust. Another finding noted by Haney (2001) was that the younger offenders entering prison become more institutionalized (transformed) because they have not yet formed the ability and expectation to control their own life choices. At least for the aged delinquent at LSP, the punishment adjustment variable was showed to be the strongest variable to significantly determine desistance among a sample. Why was adjustment the strongest goes beyond the scope of this research and therefore requires a need for further study. On the other hand, the After-study results showed that the only predictability with respect to desistance among any of the predictor variables was employment, particularly, type of work. When comparing the desisters among the aged delinquents, juvenile lifers (younger group) desisted less than young adult lifers (older group), although no significant differences were found in the desistance rate of these aged-delinquent subgroups in the sample population.

\section{REFERENCES}

Amnesty International USA, (2005, October). The rest of their lives: Life without parole for child offenders in U. $S$. New York, New York: Amnesty International.

Andenaes, J. (1968). Does punishment deter crime? Criminal Law Quarterly, 11, 76-93.

Bennett, W. J., Dilulio, J. J., Jr., \& Walters, J. P. (1996). Body count: Moral poverty and how to win America's war against crime and drugs. New York: Simon \& Schuster

Blumstein, A., Cohen, J., \& Farrington, D. P. (1988). Criminal career research: Its value for criminology. Criminology, 26, 1-35.

Blumstein, A., Cohen, J., Roth, J. A. \& Vishers, C. A. (1986). Criminal careers and career criminals. Washington, DC: National Academy Press.

Blumstein, A. \& Cork, D. (1996). Linking gun availability to youth gun violence. Law and Contemporary Problems 59(1): 5-37.

Blumstein, A., Farrington, D.P. \& Moitra, S. (1984). Delinquency careers: Innocents, amateurs, and persisters. Crime and Justice: A Review of Research 6: 187-219.

Bushway, S. D., (2007). The inextricable link between age and criminal history in Bushway, S. D., Piquero, A., Broidy, L., Cauffman, E., \& Mazerollo, P. (2001). An empirical framework for studying desistance is a process. Criminology, 39, 491-515.

Cook, P. J., \& Laub, J. H. (1998). The unprecedented epidemic in youth violence. Pp. 27-64 in Youth violence, crime and justice, vol. 24, M. Tonry and M.H. Moore, eds. Chicago: University of Chicago Press.

Commission on Behavior and Social Sciences and Education. (2001). Juvenile crime: Juvenile justice. McCord, Wisdom, \& Crowell (Eds.) Washington, DC: National

Cunningham, P., \& Henggeler, S. (1999). Engaging multiproblem families in treatment: Lessons learned throughout the development of multisystemic therapy. Family Process, 38, 265-281.

Doob, A. N., Sprott, J. B., Marinos, V., Varma, K. N. (1998). An exploration of Ontario residents' views of crime and the criminal justice system. Toronto, Ont.: University of Toronto, Centre of Criminology.

Doob, A. N., Marinos, V., \& Varma, K. N. (1995). Youth crime and the youth justice system in anada: Centre of Criminology, University of Toronto.

Elliott, D. S. (1994). Serious violent offenders: Onset, developmental course and termination. Criminology, 32 (1), 1-21.

Fagan, J. \& Freeman, R. (1999). Crime, work, and unemployment. In M. Tonry (Ed.), Crime and justice: A review of research (pp. 225-290). Chicago: University of Chicago Press.

Feld, B. C. (1987). The juvenile court meets the principle of the offense: Legislative changes in juvenile waivers statutes. Criminal Law \& Criminology, 78, 471-474. 
Gendreau, P., Goggin, C., \& Cullen, F. T. (1999). The effects of prison sentence on recidivism. Corrections Research, Department of the Solicitor General Canada, Special Report. Ottawa, Ontario, Canada.

Gonzales, A. R., Schofiled, R. B., \& Schmitt, G. (2005). Co-Offending and patterns of juvenile crime. Washington, DC: National Institute of Justice.

Griffin, P., Torbet, G. P. \& Szymanski, L. (1998). Trying juveniles as adults in criminal court: An analysis of stats transfer provisions. Report. Washington, DC: U. S. Department of Justice, Office of Juvenile Justice Programs, Office of Juvenile Justice and Delinquency Presentation. Juvenile Court Statistics. (1996). Assessing the exposure of urban youth to violence. NIJ 184414.

Haney, C. (2001). The psychological impact of incarcerated: Implications for post-prison adjustment. Paper presented at the National Policy Conference on January 30-31, 2002. Washington, DC: U. S. Department of Health and Human Services).

Kelley, B., Huizinga, D., Loeber, R., and Thornberry, T.P. (1997). Epidemiology of serious violence, Juvenile Justice Bulletin, June. Office of Juvenile Justice and Delinquency Prevention, Washington, DC.: U.S. Department of Justice.

Kelley, B. T., Loeber, R., Keenan, K, \& DeLamatre, M., (1997, December). Developmental pathways in boys' disruptive and delinquent behavior. Juvenile Justice Bulletin (NCJ No.165692).

Kuhn, D.\& Lao, J. (1996). Effects of evidence on attitudes: Is polarization the norm? Psychological Science, 7 , $115-120$

Laub, J. H. \& Sampson, R. J. (2003). Shared beginning, divergent lives: Delinquent boys to age 70. Cambridge, Mass.: Harvard University Press.

Laub, J. H. \& Sampson, R. J. (2001). Understanding desistance from crime. In crime and justice: A review of research. Chicago: University of Chicago Press.

Loeber, R. (1996). Developmental continuity, change, and pathways in male juvenile problem behaviors and delinquency. In J. D. Hawkins (Ed.), Delinquency and crime: Current theories (pp. 1-27). New York: Cambridge University Press.

Loeber, R., Farrington, D. P., \& Waschbusch, D.A. (1998). Serious and violent juvenile offenders. Pp. 13-29 in Serious and Violent Juvenile Offenders: Risk Factors and Successful Interventions, R. Loeber and D.P. Farrington, eds. Thousand Oaks, CA: Sage.

Loeber, R. (1996). Developmental continuity, change, and pathways in male juvenile problem behaviors and delinquency. In J. D. Hawkins (Ed.), Delinquency and crime: Current theories (pp. 1-27). Cambridge University Press

McShane, M. D. \& Williams III, F. P. (1989). The prison adjustment of juvenile offenders. Crime \& Delinquency, 55, 2, 254-269.

Moffitt, T. E. (1993). Adolescence-limited and life-course persistent anti-social behavior: A developmental taxonomy. Psychological Review 100, 674-701.

Mukherjee, S. (1997). Juvenile crime: Overview of changing patterns. Paper presented at the Australian Institute of Criminology Conference Adelaide, Australia.

Mulvey, E. P., Steinberg, L., Cauffman, E., Piquero, A. P., Chassin, L., Brame, R., Schubert, C. A., Hecker, T. \& Losoya. S. H. (2004). Theory and research on desistance from anti-social activity among serious adolescent offenders. Youth Violence and Juvenile Justice. 2, 3, 213-236.

Nagin, D. S. (2005). Group-Based Modeling of Development over the Life Office of Juvenile Justice and Delinquency Prevention. (1996). Serious habitual offender. Washington, DC: U. S. Department of Justice.

Office of Juvenile Justice and Delinquency Prevention. (1996). Combating violence and delinquency. The National Juvenile Justice Action Plan. NCJ 157105.

O’Shaughnessy, R. J. \& Andrade, H. (2004). Forensic psychiatry and violent adolescents. Medscape Today, 4. Retrieved from www.medscape.com/viewarticles/571434

Piquero, A. R., Farrington, D. P., \& Blumstein, A. (2003). The criminal career paradigm: Background and recent development. In Crime and justice: A review of research. Chicago: University Chicago Press.

Redding, R. E. (2003). The effect of adjudicating and sentencing youths as adults. Youth Violence and Juvenile Justice, 1 (2), 128-155.

Sampson, R. J., \& Laub, J. H. (1995). Understanding variability in lives through time: Contributions of lifecourse criminology. Studies on crime and crime prevention, 4, 143-158.

Shalala, D. (2001). Youth violence: A report of Surgeon General. Presentation of the Surgeon General's Report on violent careers and anti-social or delinquent behavior. Washington, U. S. Department of Health and Human Services, Office of Juvenile Justice \& Delinquency Prevention. Retrieved form http://sgeropts.nlm.nih.gov/NN/

Siegel, L. J., Welsh, B. C., \& Senna, J. J. (2003). Juvenile delinquency: theory, practice \& law. $8^{\text {th }}$ (Ed.) Belmont: CA.: Wadsworth Publish Company.

Spelman, W. (1995). The severity of intermediate sanctions. Journal of Research in Crime and Delinquency, 32, 
$107-135$

Snyder, H. N. (1998). Juvenile arrests 1997. Office of Juvenile Justice and Delinquency Prevention. Washington, DC. U. S. Department of Justice Programs.

Snyder, H. N. \& Sickmund, M. (2006). Juvenile offenders and victims: 2006 national report. Washington, D. C. Office of Juvenile Justice and Delinquency, NCJ 178257.

Snyder, H. N. \& Sickmund, M. (1999). Juvenile offenders and victims: 1999 national report. Washington, DC. Office of Juvenile Justice and Delinquency, NCJ 178257.

Snyder, H., and M. Sickmund. 1995 (May). Juvenile offenders and victims: A focus on violence. Washington, D.C.: Office of Juvenile Justice and Delinquency Prevention, U.S. Department of Justice. NCJ 153570.

Stahl, A. (1999). Delinquency cases waived to criminal court, 1987-1996. Washington, DC. Office of Juvenile Justice and Delinquency Prevention.

Thomas, Merritt. (2007, May). Personal Interview

Tolan, P. H. (1987). Implications of onset for delinquency risk identification. Journal of Abnormal Child Psychology, 15, 47-65.

Tolan, P.H., \& Gorman-Smith, D. (1998). Development of serious, violent and chronic offenders. In R. Loeber \& D. Farrington (Eds.). Never too early, never too late: Serious, violent, and chronic juvenile offenders. (pp. 68-65). Beverly Hills, CA: Sage

Torbet, P., Gable, R., Hurst H., IV, Montgomery, I., Szymanski, L. \&, Thomas, D. (1996). State responses to serious and violent juvenile crime. Washington DC : Office of Juvenile Justice and Delinquency Prevention.

U. S. Surgeon General (2001). Youth violence: A report of the surgeon general. Washington, DC: Department of health and Human Services.

Van Voorhis, P. (2004). An overview of offender classification systems. In P. Van Voorhis, M. Braswell, \& D. Lester (Eds.), Correctional counseling and rehabilitation (5th ed.), (pp. 133-16).

Van Voorhis, P., Browning, S. L., Simon, M., \& Gordon, J. (1997). The meaning of punishment: Inmates' orientation to the prison experience. The Prison Journal, 77, 135-167

Warr, M. (1998). Life course transitions and desistance from crime. Criminology, 36, 183-216.

Wilcox, N. \& Steele, T. (2003). Just the facts: A descriptive analysis of inmate attitudes toward capital punishment. The Prison Journal, 83 (4), 464-482.

Zimring, F. E. (1998). American youth violence. Oxford, United Kingdom: Oxford University Press. 